The spore trap was set up at a height of $6 \mathrm{ft}$. above ground-level. A thin film of paraffin and rubber lubricant spread over the slide surface was found to be a satisfactory sticker. The treated slides were easily placed in position, were protected from rain, and could be changed as frequently as desired.

Such a spore trap has been in operation for more than a year and has given very satisfactory results.

I am indebted to Flight Lieut. H. Pringle, of the Royal Rhodesian Air Force, for his practical assistance and advice in connexion with the development of the spore trap.

R. C. STEPHEN

Tobacco Research Board of Rhodesia and Nyasaland, P.O. Box 1909, Salisbury, S. Rhodesia.

\section{Appraisement of Total Activity in Laboratory Animals}

THE effect of environmental conditions on the activity of small laboratory animals is usually recorded in terms of locomotor activity as indicated by the revolutions of rotating cages. Work in progress with an animal calorimeter ${ }^{1}$ indicates that a considerable amount of time and energy is spent in other activities such as washing, scratching and gnawing. The apparatus described below has been constructed to record evidence of all types of activity.

A triangular plywood table has three metal legs ending in flexible feet made from short lengths of rubber tubing. Half-way down its length each tube is encircled by a metal cylinder. The rubber tube stands on the base of a copper vessel the inner vertical surface of which is insulated. This vessel contains carbon granules which provide a resistive path between its base and the metal cylinder. These three carbon resistance units are connected in series with an accumulator and a fixed resistor.

The animal, in a light cage, is placed on the table. As the animal moves the table vibrates, thus changing the resistance of the carbon units. This gives rise to a variation in the current and hence in the potential difference across the fixed resistor. This variation in potential difference is amplified and applied to a pen recorder.
${ }^{1}$ Hirst, J. M., Ann. App. Biol., 39, 257 (1952).

\section{New Routes to Tetrahalomethanes}

Tetrahalomethanes, such as carbon tetrachloride, dichlorodifluoromethane, or ehlorotrifluoromethane, are prepared commercially in a variety of ways. New routes to such compounds have now been found starting from carbonyl halides such as $\mathrm{COCl}_{2}, \mathrm{COF}_{2}$. $\mathrm{COFCl}$ or $\mathrm{COFBr}$.

Reaction of phosgene with phosphorus pentachloride at $350^{\circ} \mathrm{C}$. under pressure yields carbon tetrachloride in 60 -70 per cent conversion. Carbonyl fluoride similarly gives dichlorodifluoromethane be tween $100^{\circ}$ and $400^{\circ} \mathrm{C}$, though in much lower yield : $\mathrm{COX}_{2}+\mathrm{PCl}_{5} \rightarrow \mathrm{CX}_{2} \mathrm{Cl}_{2}+\mathrm{POCl}_{3} ; X=\mathrm{F}$ or $\mathrm{Cl}$ Chlorotrifluoromethane, carbonyl chlorofluoride, and, under certain conditions, carbon tetrachloride, are also produced when $X=\mathrm{F}$ by the following sidereactions :

$$
\begin{aligned}
& \left.\mathrm{COF}_{2} \stackrel{\mathrm{PCl}_{5}}{\stackrel{\mathrm{COFCl}}{\rightleftharpoons} \mathrm{COCl}} \text { ( }+\mathrm{PF}_{3} \mathrm{Cl}_{2}, \text { ete. }\right) \\
& \mathrm{COCl}_{2} \stackrel{\mathrm{PCl}_{5}}{\longrightarrow} \mathrm{CCl}_{4} \\
& \mathrm{CF}_{2} \mathrm{Cl}_{2}+\mathrm{COF}_{2} \rightarrow \mathrm{CF}_{3} \mathrm{Cl}+\mathrm{COFCl} \\
& 2 \mathrm{CF}_{2} \mathrm{Cl}_{2} \rightleftharpoons \mathrm{CFCl}_{3}+\mathrm{CF}_{3} \mathrm{Cl}
\end{aligned}
$$

Phosphorus trifluoridedichloride, $\mathrm{PF}_{3} \mathrm{Cl}_{2}$, or phosphorus pentafluoride, can be used instead of phosphorus pentachloride for reaction with phosgene; similarly, earbonyl chlorofluoride can be treated with phosphorus pentachloride.

It is known that phosphorus oxychloride can be reconverted to phosphorus pentachloride by reaction with carbon monoxide or phosgene in presence of carbon :

$\mathrm{POCl}_{3}+\mathrm{CO}\left(\right.$ or $\left.\mathrm{COCl}_{2}\right) \stackrel{\mathrm{C}}{\rightarrow} \mathrm{PCl}_{3}$ (or $\mathrm{PCl}_{5}$ ) $+\mathrm{CO}_{2}$

Reaction of carbon monoxide, chlorine and phosphorus trichloride is thus the basis of this synthesis of carbon tetrachloride which involves the conversion of acyl carbonyl into $\mathrm{CCl}_{2}$.

Fluorochloromethanes have also been obtained by pyrolysis or copyrolysis of carbonyl halides in flow systems or in an autoclave, for example,

$$
\mathrm{COF}_{2}+\mathrm{COCl}_{2} \rightarrow \mathrm{CF}_{2} \mathrm{Cl}_{2}+\mathrm{CO}_{2}
$$$$
2 \mathrm{COFCl} \rightarrow \mathrm{CF}_{2} \mathrm{Cl}_{2}+\mathrm{CO}_{2}
$$

Temperatures between $250^{\circ}$ and $700^{\circ} \mathrm{C}$. are used, and the conversions are greatest under superatmospheric pressure. Carbonyl chlorofluoride, trichlorofluorometh. ane, chlorotrifluoromethane, carbon tetrafluoride and carbon tetra. chloride are by-products in amounts

A typical trace for a single mouse $(25 \mathrm{gm}$.) in a standard cage $(600 \mathrm{gm}$.) is shown in Fig. 1. The trace was recorded on an 'Ediswan' oscillograph (type EPR). The sensitivity to movement can be varied by altering the length of rubber tubing as well as by adjusting the amplifier gain. This enables background vibrations to be eliminated. As the vibrations of the table are heavily damped, the trace obtained follows animal movement very closely.

$$
\text { E. G. C. Ciarke }
$$

A. E. HaWkINS

Department of Physiology,

Royal Veterinary College,

London, N.W.1. March 22.

${ }^{1}$ Clarke, E. G. C., and Hawkins, A. E., Phys. Med. Biol., 1, 118 (1956). depending upon the temperature and pressure used :

$$
\begin{aligned}
& \mathrm{COF}_{2}+\mathrm{COCl}_{2} \rightleftharpoons 2 \mathrm{COFCl} \\
& \mathrm{COF}_{2}+\mathrm{COFCl} \rightarrow \mathrm{CF}_{3} \mathrm{Cl}+\mathrm{CO}_{2} \\
& \mathrm{COFCl}+\mathrm{COCl}_{2} \rightarrow \mathrm{CFCl}_{3}+\mathrm{CO}_{2} \\
& 2 \mathrm{COF}_{2} \rightarrow \mathrm{CF}_{4}+\mathrm{CO}_{2}
\end{aligned}
$$

Reaction of phosgene, or of carbon monoxide and chlorine, with hydrogen fluoride thus provides a new route to the useful compound dichlorodifluoromethane :

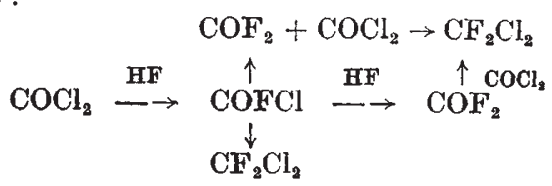

